\title{
KEMITRAAN PERUSAHAAN ISLAMI DENGAN PERBANKAN SYARIAH GUNA PENINGKATAN INCOME MELALUI JUAL BELI ONLINE DI KOTA BOGOR
}

\section{ISLAMIC COMPANIES PARTNERSHIP WITH SYARIAH BANKING IN INCOME INCREASE THROUGH ONLINE BUYING AND SELLING IN BOGOR CITY}

\author{
Furqonul Haq1a; Sahlan Hasbi² \\ 1aDosen Program Studi Ekonomi Syariah Fakultas Ekonomi Islam Universitas \\ Djuanda Bogor, e-mail: furqonul.haq@unida.ac.id \\ 2Dosen Program Studi Ekonomi Syariah Fakultas Ekonomi Islam Universitas \\ Djuanda Bogor, e-mail: sahlan.hasbi@unida.ac.id
}

(Diterima oleh Dewan Redaksi 29-11-2017)

(Dipublikasikan oleh Dewan Redaksi 18-12-2017)

\begin{abstract}
This study aims to determite how the public perception of the city of Bogor towards Islamic mortgage scheme. In this study using quantitative descriptive method and using the Likert method of analysis and Chi square. The primary data were taken using a questionnaire method by sampling using methods slovin many as (100) samples of inhabitants of the city of Bogor. The results of the calculation method of Chi square values obtained at 84.100 . so the result of Chi square count is greater than Chi squared table of $84.100>13.277$ so Ho in this study is rejected and Ha is accepted or can be concluded that there is a different between the mortgage in Islamic banks and mortgage in conventional banks according by public perception of the city of Bogor.
\end{abstract}

Keywords : Perception, , The society of Bogor, Islamic mortgage

\begin{abstract}
ABSTRAK
Penelitian ini bertujuan untuk mengetahui kemitraan perusahaan Islami dan perbankan syariah di kota Bogor. Metode penelitian menggunakan metode deskriptif kualitatif dengan pendekatan studi kasus. Jumlah sampel sebanyak 2 buah sampel (perusahaan Islami di Bogor). Berdasarkan hasil penelitian dapat dikatakan bahwa masih banyak perusahaan Islami di Bogor yang masih belum menggunakan bank syariah dan melakukan jual beli secara online. Pola kemitraan yang dijalin oleh perusahaan Islami dengan bank syariah adalah penggunaan rekening bank syariah dengan memanfaatkan jasa-jasa lain (fee based), seperti internet banking, sms banking, dan transfer (ATM). Perusahaan Islami belum memanfaatkan jasa pembiayaan dari bank syariah. Tidak terdapat perbedaan yang signifikan antara perolehan income perusahaan Islami sebelum dan sesudah bermitra dengan bank syariah di kota Bogor.
\end{abstract}

Kata Kunci: Kemitraan, Perusahaan Islami, Bank Syariah, Income. 
Furqonul Haq. 2017. Kemitraan Perusahaan Islam dengan Perbankkan Syariah Guna Peningkatan Income Melalui Jual Beli Online di Kota Bogor. Jurnal Nisbah 3 (2): $424-432$

\section{PENDAHULUAN}

Jual beli barang dan jasa yang dilakukan oleh individu biasanya memiliki metode penjualan yang tidak bervariatif. Sementara jual beli barang dan jasa yang dilakukan oleh perusahaan biasanya memiliki metode penjualan yang bervariatif. Salah satu metode penjualan yang sering dilakukan perusahaan di masa sekarang adalah dengan menjual produk melalui sistem online.

Jual beli produk dengan sistem online sering disebut dengan jual beli online. Jual beli online atau perdagangan elektronik (electronic commerce atau $e$ commerce) adalah penjualan atau pembelian barang dan jasa, antara perusahaan, rumah tangga, individu, pemerintah, dan masyarakat atau organisasi swasta lainnya yang dilakukan melalui komputer pada media jaringan. Barang-barang dan jasa-jasa dipesan melalui jaringan tersebut, tetapi pembayaran dan pengiriman barang atau jasa dapat dilakukan melalui bantuan media perbankan.

Perusahaan online yang Islami dalam menjalankan aktivitas transaksinya tentunya juga perlu didukung oleh perbankan, dalam hal ini adalah perbankan syariah. Hal ini disebabkan oleh karena perusahaan Islami adalah perusahaan yang menjalankan aktifitas bisnisnya hanya yang sesuai aturan syariat, serta hanya melakukan transaksi bisnis yang halal. Jika perusahaan Islami yang melakukan jual beli bermitra dengan perbankan syariah maka akan didapatkan kondisi saling menguntungkan bagi kedua belah pihak. Bagi perusahaan yang memanfaatkan jasa perbankan syariah akan dimudahkan dalam menerima pembayaran dari para konsumen dan dimudahkan dalam melakukan pembayaran kepada supplier perusahaan. Bagi Bank Syariah, kondisi ini memungkinkan untuk meningkatkan pendapatan bank yang bersumber dari pembiayaan, pendanaan maupun fee based income yang diperoleh bank syariah atas setiap transaksi perbankan yang dilakukan perusahaan Islami di bank syariah.

Berdasarkan penjelasan diatas, penulis tertarik untuk melakukan penelitian tentang kemitraan perusahaan Islami dan perbankan syariah di kota Bogor. Tujuan dari penelitian ini adalah untuk mengetahui apa jasa teknologi perbankan syariah yang digunakan perusahaan Islami sebagai sistem pembayaran dalam jual beli online, bagaimana pola kemitraan yang dijalin oleh perusahaan Islami dengan bank syariah, apakah terdapat perbedaan yang signifikan antara income perusahaan Islami yang diperoleh sebelum dan sesudah bermitra dengan bank syariah.

\section{MATERI DAN METODE}

\section{Tempat dan Waktu Penelitian}

Penelitian ini akan dilaksanakan di Bogor untuk kota Bogor dan kabupaten Bogor dengan sebaran keduanya proposional berdasarkan banyaknya jumlah perusahaan Islami yang ada di masing-masing wilayah. Waktu penelitian akan dilakukan selama 8 bulan dari bulan Maret 2017 sampai dengan November 2017.

\section{Definisi Operasional Variabel}

Variabel dalam penelitian ini adalah variabel perusahaan Islami, 
variabel pola kemitraan perusahaan Islami dengan Bank syariah, variabel jasa teknologi perbankan syariah dan jasa perbankan syariah lainnya serta variabel income.

\section{Desain Penelitian}

Jenis penelitian ini akan dilakukan survei kualitatif yang akan disajikan secara deskriptif. Hal ini dilakukan untuk memberikan gambaran atau uraian atas suatu keadaan sejelas mungkin tanpa ada perlakuan terhadap obyek yang diteliti (Kountur, 2003). Tujuan dari penelitian deskriptif adalah untuk membuat kajian mendalam dan gambaran secara sistematis, faktual dan akurat mengenai fenomena atau hubungan antara fenomena yang diteliti.

\section{Populasi dan Teknik Pengumpulan Data}

Populasi dari penelitian ini adalah seluruh perusahaan Islami dan bank syariah yang ada di Bogor. Jumlah sampel yang digunakan sesuai dengan kebutuhan pemenuhan standar penelitian kualitatif. Teknik sampling dengan menggunakan purposive sampling dan convenience sampling. Oleh karena itu, berapapun jumlah sampel dalam penelitian ini adalah valid untuk dilakukan. Dalam penelitian ini, jumlah sampel berjumlah 2 buah sampel penelitian.

\section{Analisis Data}

Analisis penelitian dilakukan dengan analisis kualitatif dengan metode deskriptif. Sebelum melakukan analisis data maka dilakukan pengumpulan data. Setelah data terkumpul kemudian dilakukan interview terhadap bank-bank syariah berkaitan dengan jasa-jasa teknologi perbankan yang ada pada bank-bank syariah dan jasa mana saja yang telah digunakan perusahaan Islami sebagai sistem pembayaran dalam jual beli online, serta apakah bank syariah belum atau sudah bermitra dengan perusahaan Islami dalam kegiatan jual beli online. Selanjutnya dilakukan interview terhadap perusahaan Islami berkaitan dengan income yang diperoleh perusahaan Islami sebelum dan sesudah adanya kemitraan dengan perbankan syariah. Setelah dilakukan interview kepada perusahaan Islami dan bank syariah, kemudian dilakukan analisa terhadap semua data yang diperoleh.

\section{HASIL DAN PEMBAHASAN}

\section{Gambaran Umum Perusahaan Islami di Kota Bogor}

Perusahaan Islami adalah perusahaan yang patuh terhadap ketentuan syariah. Perusahaan Islami tentu menjalankan kegiatan bisnisnya secara syar'i. Perusahaan Islami hanya memproduksi produk (misalnya makanan dan minuman) yang sudah jelas kehalalannya. Salah satu indikator kehalalan produk adalah produk telah memiliki Sertifikasi Halal dari LPPOM MUI.

Batasan perusahaan Islami dalam penelitian ini adalah perusahaan yang produknya telah tersertifikasi Halal LPPOM MUI. Di Kota Bogor terdapat kurang lebih 74 perusahaan yang produknya telah tersertifikasi Halal LPPOM MUI. Sementara di Kabupaten Bogor terdapat kurang lebih 325 perusahaan yang produknya telah tersertifikasi Halal LPPOM MUI. Dari data tersebut dapat diketahui bahwa tidak banyak perusahaan Islami di Bogor yang melakukan transaksi jual beli online dan menggunakan rekening Bank Syariah dalam aktivitas bisnisnnya. Dalam penelitian ini digunakan 3 sampel perusahaan Islami, yang terdiri dari 2 perusahaan Islami di Kota Bogor dan 1 perusahaan Islami di Kabupaten Bogor. 
Jasa Teknologi Perbankan Syariah Yang Digunakan Perusahaan Islami Sebagai Sistem Pembayaran Dalam Jual Beli Online

1. Delishfood

Delishfood adalah perusahaan Islami yang bergerak dalam bidang olahan peternakan, seperti bakso, sosis, dan nugget. Produk bakso, sosis, dan nugget yang dihasilkan adalah produk non MSG dan non pengawet. Delishfood dirintis oleh Rayis Utsman, Bayu Rizki Faozi, dan Abdul Halim. Delishfood dimulai pada tahun 2014 dan secara professional berdiri pada tanggal 1 September tahun 2015. Delishfood berada di Gedung INCUBIE IPB Leuwi Kopo, Kampus IPB Dramaga, Kabupaten Bogor. Bisnis Delishfood diawali dengan berjualan bakso bakar di sekitar Kampus IPB Dramaga, kemudian dari tahun 2016 hingga sekarang beralih produk menjadi frozen food bakso, sosis, dan nugget. Delishfood melakukan penjualan secara online ataupun offline. Penjuaalan yang dilakukan Delishfood setiap bulannya kurang lebih menghasilkan omzet 10-20 juta per bulannya.

Delishfood melakukan penjualan online melalui website (www.delishfoodindonesia.com),

facebook, dan instagram. Delishfood tidak menitipkan produk-produknya di toko online. Dalam mengirimkan produk yang dibeli oleh konsumen secara online, Delishfood melaksanakan ekspedisi sendiri dan menggunakan jasa Gosend.

Delishfood menggunakan rekening bank konvensional dan bank syariah. Rekening tersebut terdiri dari rekening di Bank BNI, BRI, BNI Syariah, serta BSM. Jasa teknologi perbankan syariah yang digunakan Delishfood sebagai sistem pembayaran dalam jual beli online terdiri dari internet banking dan transfer (ATM).

\section{Dawa}

Dawa adalah perusahaan Islami yang bergerak dalam bidang olahan minuman obat serbuk yang berbahan jahe merah. Produk minuman jahe merah yang dihasilkan adalah produk non pengawet. Dawa dirintis oleh Ida Laila. Dawa dimulai dari tahun 2012. Dawa berada di Jl. Adnan Wijaya Kp.Ceger RT 01 RW 13 Kel.Tegal Gundil Kec. Bogor Utara Kota Bogor. Bisnis Dawa diawali oleh Ida Laila setelah beliau mengikuti pelatihan Tanaman Obat Keluarga (TOKA) di Disperindag Kota Bogor, setelah mengikuti pelatihan tersebut, maka Ida Laila mulai menjalankan bisnis Dawa hingga sekarang. Dawa melakukan penjualan secara online ataupun offline. Penjuaalan yang dilakukan Dawa setiap bulannya kurang lebih menghasilkan omzet 3-4 juta per bulannya.

Dawa melakukan penjualan online melalui facebook dan instagram. Dawapun menitipkan produk-produknya di toko online, seperti Tokopedia dan BLANJA.com. Dalam mengirimkan produk yang dibeli oleh konsumen secara online, Dawa melaksanakan ekspedisi sendiri dan menggunakan jasa Gosend, UBER dan J \& T.

Dawa menggunakan rekening bank konvensional dan bank syariah. Rekening tersebut terdiri dari rekening di Bank BJB dan BSM. Jasa teknologi perbankan syariah yang digunakan Dawa sebagai sistem pembayaran dalam jual beli online terdiri dari sms banking dan transfer (ATM).

\section{Pola Kemitraan Yang Dijalin oleh Perusahaan Islami dengan Bank Syariah}

1. Delishfood

Pola kemitraan yang dijalin oleh Delishfood dengan bank syariah adalah penggunaan rekening bank syariah dengan memanfaatkan jasa-jasa lain (fee based), seperti internet banking, sms banking, dan transfer (ATM). Delishfood 
tidak memanfaatkan jasa pembiayaan dari bank syariah.

\section{Dawa}

Pola kemitraan yang dijalin oleh Dawa dengan bank syariah adalah penggunaan rekening bank syariah dengan memanfaatkan jasa-jasa lain (fee based), seperti sms banking dan transfer (ATM). Dawa tidak memanfaatkan jasa pembiayaan dari bank syariah.

Perolehan Income Perusahaan Islami Sebelum dan Setelah Bermitra dengan Bank Syariah

1. Delishfood

Perolehan income Delishfood sebelum bermitra dengan bank syariah adalah lebih kecil dibandingkan setelah bermitra dengan bank syariah. Data tersebut diperoleh melaui data histori omzet Delishfood yang peneliti dapatkan dari pihak Delishfood. Secara rinci, income Delishfood sebelum dan sesudah bermitra dengan bank syariah dapat dilihat pada Tabel 1 dan Tabel 2 berikut:

Tabel 1. Income Delishfood Sebelum

Bermitra Dengan Bank Syariah

\begin{tabular}{|c|r|c|c|}
\hline \multicolumn{4}{|c|}{ Sebelum Menggunakan Bank Syariah } \\
\hline Bulan & BS & BK & Total \\
\hline Feb-16 & 0 & $6,000,000$ & $6,000,000$ \\
\hline Mar-16 & 0 & $7,000,000$ & $7,000,000$ \\
\hline Apr-16 & 0 & $10,000,000$ & $10,000,000$ \\
\hline Mei-16 & 0 & $12,000,000$ & $12,000,000$ \\
\hline Jun-16 & 0 & $12,000,000$ & $12,000,000$ \\
\hline Jul-16 & 0 & $15,000,000$ & $15,000,000$ \\
\hline Agust-16 & 0 & $15,000,000$ & $15,000,000$ \\
\hline Sep-16 & 0 & $10,000,000$ & $10,000,000$ \\
\hline Okt-16 & 0 & $8,000,000$ & $8,000,000$ \\
\hline \multicolumn{3}{|c|}{ Total } & $95,000,000$ \\
\hline \multicolumn{3}{|c|}{ Rata-rata } & $10,555,556$ \\
\hline
\end{tabular}

Sumber: data diolah penulis.
Tabel 2. Income Delishfood Sesudah

Bermitra Dengan Bank Syariah

\begin{tabular}{|c|c|c|c|}
\hline \multicolumn{4}{|c|}{ Sesudah Menggunakan Bank Syariah } \\
\hline Bulan & BS & BK & Total \\
\hline Nop-16 & $8,000,000$ & - & $8,000,000$ \\
\hline Des-16 & $9,000,000$ & - & $9,000,000$ \\
\hline Jan-17 & $5,000,000$ & $6,000,000$ & $11,000,000$ \\
\hline Feb-17 & $6,000,000$ & $5,000,000$ & $11,000,000$ \\
\hline Mar-17 & $7,000,000$ & $5,000,000$ & $12,000,000$ \\
\hline Apr-17 & $5,000,000$ & $5,000,000$ & $10,000,000$ \\
\hline Mei-17 & $6,000,000$ & $6,000,000$ & $12,000,000$ \\
\hline Jun-17 & $7,000,000$ & $5,000,000$ & $12,000,000$ \\
\hline Jul-17 & $9,000,000$ & $6,000,000$ & $15,000,000$ \\
\hline \multicolumn{3}{|c|}{ Total } & $100,000,000$ \\
\hline \multicolumn{3}{|c|}{ Rata-rata } & $11,111,111$ \\
\hline
\end{tabular}

Sumber: data diolah penulis.

Berdasarkan Tabel 2. di atas, diketahui bahwa rata-rata income Delishfood sebelum bermitra dengan bank syariah adalah sebesar Rp. 10.555.556,-. dan income Delishfood sebelum bermitra dengan bank syariah adalah sebesar Rp. 11.111.111,-. Perbandingan perolehan income Delishfood terbatas hanya atas income yang diperoleh melalui transaksi perbankan dan dihitung hanya berdasarkan saat Delishfood bermitra dengan bank konvensional dan bank syariah dengan menggunakan produk bank sebagai sarana transaksi, baik kepada supplier maupun kepada buyer. Income yang diperoleh Delishfood sebelum dan sesudah bermitra dengan bank syariah tidak menunjukkan angka yang signifikan, hal ini bisa dimaklumi karena penggunaan produk perbankan syariah masih dibarengi dengan penggunaan produk bank konvensional, sehingga produk bank syariah masih sebagai alternatif produk teknologi yang digunakan oleh Delishfood, bukan sebagai pilihan utama. Pilihan Delishfood atas produk teknologi perbankan lebih 
didasari atas kemudahan transaksional yang bisa diperoleh, baik produk teknologi yang ditawarkan oleh bank syariah maupun oleh bank konvensional yang didasarkan atas kemudahan dan kenyamanan bertransaksi dengan mitra Delishfood (supplier dan buyer).

2. Dawa

Perolehan income Dawa sebelum bermitra dengan bank syariah adalah lebih kecil dibandingkan setelah bermitra dengan bank syariah. Data tersebut diperoleh melaui data histori omzet Dawa yang peneliti dapatkan dari pihak Dawa. Secara rinci, income Dawa sebelum dan sesudah bermitra dengan bank syariah dapat dilihat pada Tabel 3 dan Tabel 4 berikut:

Tabel 3. Income Dawa Sebelum Bermitra

Dengan Bank Syariah

\begin{tabular}{|c|c|c|c|}
\hline \multicolumn{4}{|c|}{ Sebelum Menggunakan Bank Syariah } \\
\hline Bulan & BS & BK & Total \\
\hline Sep-16 & 0 & 840,000 & 840,000 \\
\hline okt-16 & 0 & 750,000 & 750,000 \\
\hline Nop-16 & 0 & 630,000 & 630,000 \\
\hline \multicolumn{3}{|c|}{ Total } & $2,220,000$ \\
\hline \multicolumn{3}{|c|}{ Rata-rata } & 740,000 \\
\hline
\end{tabular}

Sumber: data diolah penulis.

Tabel 4. Income Dawa Sesudah Bermitra

Dengan Bank Syariah

\begin{tabular}{|c|c|c|c|}
\hline \multicolumn{4}{|c|}{ Sesudah Menggunakan Bank Syariah } \\
\hline Bulan & BS & BK & Total \\
\hline Jan-17 & 125,000 & 800,000 & 925,000 \\
\hline Feb-17 & & 630,000 & 630,000 \\
\hline \multicolumn{4}{|l|}{ Mar-17 } \\
\hline Apr-17 & & 300,000 & 300,000 \\
\hline Mei-17 & & 500,000 & 500,000 \\
\hline \multicolumn{4}{|l|}{ Jun-17 } \\
\hline Jul-17 & & 300,000 & 300,000 \\
\hline Agus-17 & 450,000 & 840,000 & $1,290,000$ \\
\hline Sep-17 & 625,000 & $1,190,000$ & $1,815,000$ \\
\hline \multicolumn{3}{|c|}{ Total } & $5,760,000$ \\
\hline \multicolumn{3}{|c|}{ Rata-rata } & $822,857,143$ \\
\hline
\end{tabular}

Sumber: data diolah penulis.
Berdasarkan tabel 3 dan 4 di atas, diketahui bahwa rata-rata income Dawa sebelum bermitra dengan bank syariah adalah sebesar Rp. 740.000,-. dan income Dawa sesudah bermitra dengan bank syariah adalah sebesar Rp. 822.857.143,. Perbandingan perolehan income Dawa terbatas hanya atas income yang diperoleh melalui transaksi perbankan dan dihitung hanya berdasarkan saat Dawa bermitra dengan bank konvensional dan bank syariah dengan menggunakan produk bank sebagai sarana transaksi, baik kepada supplier maupun kepada buyer. Income yang diperoleh Dawa sebelum dan sesudah bermitra dengan bank syariah tidak menunjukkan angka yang signifikan, hal ini bisa dimaklumi karena penggunaan produk perbankan syariah masih dibarengi dengan penggunaan produk bank konvensional, sehingga produk bank syariah masih sebagai alternatif produk teknologi yang digunakan oleh Dawa, bukan sebagai pilihan utama. Pilihan Dawa atas produk teknologi perbankan lebih didasari atas kemudahan transaksional yang bisa diperoleh, baik produk teknologi yang ditawarkan oleh bank syariah maupun oleh bank konvensional yang didasarkan atas kemudahan dan kenyamanan bertransaksi dengan mitra Dawa (supplier dan buyer).

Usulan Model Kemitraan Perusahaan Islami Sebelum Dengan Bank Syariah Dalam Peningkatan Income Melalui Jual Beli Online

Berdasarkan penelitian yang telah dilakukan, maka penulis mencoba untuk mengajukan model "Kemitraan Perusahaan Islami Dengan Bank Syariah Dalam Peningkatan Income Melalui Jual Beli Online". Model tersebut adalah sebagai berikut: 


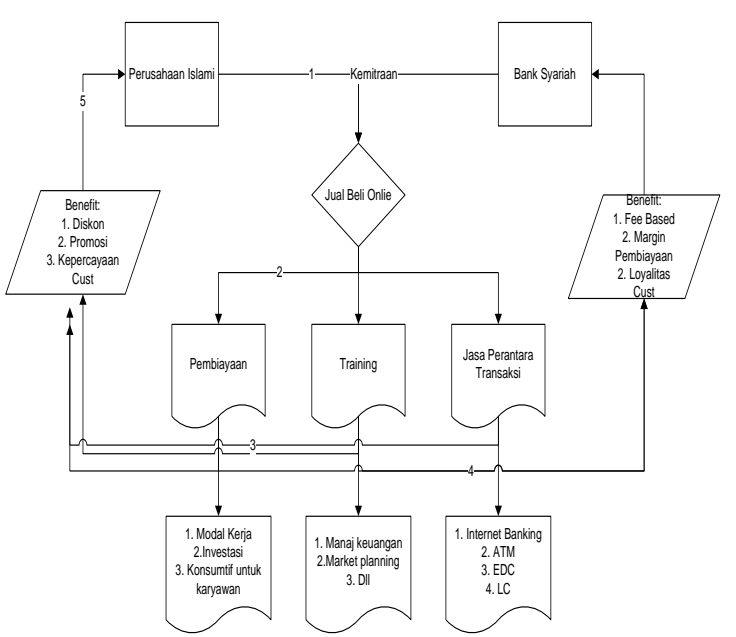

Gambar 1. Model Usulan Kemitraan

Perusahaan Islami Dengan Bank Syariah

1. Kemitraan bank syariah dan perusahaan Islami terkait jual beli online.

2. Bidang kerjasamanya adalah pembiayaan, training, dan jasa perantara transaksi.

Pembiayaan terkait penyediaan modal kerja, pembiayaan investasi, dan pembiayaan konsumtif untuk karyawan perusahaan Islami. Training terkait manajemen keuangan, market planning, dll.

3. Jasa perantara transaksi terkait internet banking, ATM, EDC, L/C, dll.

4. Benefit yang akan diperoleh bank syariah adalah fee based income, margin pembiayaan, dan loyalitas customer.

5. Benefit yang akan diperoleh perusahaan Islami adalah diskon/cashback, promosi, dan kepercayaan customer.

\section{KESIMPULAN DAN IMPLIKASI}

Jasa teknologi perbankan syariah yang digunakan perusahaan Islami di Bogor sebagai sistem pembayaran dalam jual beli online terdiri dari internet banking, SMS banking, dan transfer (ATM). Pola kemitraan yang dijalin oleh perusahaan Islami di Bogor dengan bank syariah adalah penggunaan rekening bank syariah dengan memanfaatkan jasa-jasa lain (fee based), seperti internet banking, sms banking, dan transfer (ATM). Tetapi, belum memanfaatkan jasa pembiayaan dari bank syariah. Income yang diperoleh perusahaan Islami di Bogor sebelum dan sesudah bermitra dengan bank syariah belum menunjukkan angka yang signifikan.

\section{Saran}

Bermitra dengan bank syariah bagi perusahaan Islami masih sebagai alternatif. Produk teknologi perbankan yang bisa dimanfaatkan perusahaan Islami baru sebatas penggunaan teknologi jasa pendukung transaksional, belum menyentuh kemitraan terkait pembiayaan. Oleh karena itu, saran yang yang dapat diberikan adalah sebagai berikut:

a. Saran untuk perbankan syariah: Bank Syariah harus menawarkan produkproduk teknologi perbankan yang sesuai dengan kebutuhan perusahaan Islami, bukan hanya sebatas jasa perbankan, tetapi juga penyediaan pembiaayaan yang memberikan syarat dan ketentuan yang mudah bagi perusahaan Islami, seperti peyediaan fasilitas financial technology (fintech).

b. Saran untuk perusahaan Islami: Perusahaan Islami seharusnya menjadikan bank syariah bukan sebagai pilihan utama sebagai mitra bisnis, baik terkait penggunaan teknologi perbankan untuk membantu transaksional bisnis mapun lebih jauh sebagai mitra pembiayaaan, karena bank syariah mengedepankan kehalalan dalam transaksionalnya sebagaimana delishfood sebagai perusahaanaan Islami yang mengedepankan hanya menjual produk-produk yang halal. 


\section{DAFTAR PUSTAKA}

Al-Bassam, Abdurrahman. 1992. Taudhidul Ahkam. Selangor: Pustaka Azzam.

Anto, Hendrie,M.B. 2003. Pengantar Ekonomi Mikro Islami. Yogyakarta: Ekonisia.

Ascarya. 2013. Akad dan Produk Bank Syariah. Jakarta: PT. Rajawali Press

Ash-Shan'ani, Imam. 2015. Subulus Salam. Jakarta: Darus Sunnah

Ghassani, Nabila. 2015. Kemitraan Pengembangan UMKM: Studi Deskriptif tentang Kemitraan PT. PJB (Pembangkit Jawa Bali) Unit Gresik Pengembangan UMKM Kabupaten Gresik. Jurnal Kebijakan dan Manajemen Publik Universitas Airlangga Volume 3 Nomor 2.

Hadi, Kuncoro. 2012. Implementasi Maqoshid Syariah Sebagai Indikator Perusahaan Islami, , Jurnal $A L$ AZHAR INDONESIA SERI PRANATA SOSIAL, Vol. 1, No. 3, Maret 2012. Hal 140-141

Hutabarat dan Huseini. 2006. Pengantar Manajemen Strategik Kontemporer di Tengah Operasional. Jakarta: PT. Alex Komputindo Karim, Adiwarman. 2009. Bank Islam (Analisis Fiqih dan Keuangan). Jakarta: PT. Raja Grafindo Persada.

Jauhari, Jaidan. 2010, Upaya Pengembangan Usaha Kecil dan Menengah (UKM) dengan Memanfaatkaan E-Commerce. Jurnal Sistem Informasi, Volume 2, Nomor 1, hal. 159-168.Kasmis. 2012. Bank dan Lembaga Keuangan Lainnya. Jakarta: PT. Raja Grafindo. HIm 129.

Kartasasmita, Ginandjar. 1996. Pembangunan untuk Rakyat : Memadukan Pertumbuhan dan Pemerataan. Jakarta: CIDES.

Kountour, Ronny. 2003. Metode Penelitian Untuk Menulis Skripsi Dan Tesis, Jakarta: PPM.
Laudon, Ken, and Jane Laudon. 2009. Management Information Sistems: International Edition,11/E. Pearson Higher Education.

Mardiyanto, H. 2009. Intisari Manajemen Keuangan. Jakarta: Grasindo.

Muslichah, dkk. 2012. Penggunaan Teknologi Internet dalam Sistem Penjualan Online untuk Meningkatkan Kepuasaan dan Pembelian Berulang Produk Batik pada Usaha Kecil dan Menengah di Jawa Timur. Jurnal Manajemen dan Kewirausahaan, Volume 14, Nomor 1, hal. 71-81.

Mulyasari, Hestin, dkk. 2014. Analisis Jenis Sistem Pembayaran Elektronik Dalam Transaksi ECommerce Di Indonesia. Seminar Nasional Teknologi Informasi Dan Komunikasi 2014 (Sentika 2014) Yogyakarta.

Pradana, Mahir. 2015. Klasifikasi JenisJenis Bisnis E-Commercedi Indonesia. Jurnal Neo-bis. Volume 9, No. 2.

Sabiq, Sayyid. 2009. Fiqhu as-Sunnah, Beirut: Dar al-Kitab al-Arabi

Sandhusen, Richard. 2008. Marketing. Hauppauge, N.Y: Barron's Educational Series.p.520. ISBN 07641-3932-0

Suhayati, Ely dan Sri Dewi Anggadini. 2009. Akuntansi Keuangan. Yogyakarta: Graha Ilmu Edisi Pertama,

Santoso, Imam. 2010. Akuntansi Keuangan menengah (intermediate Accounting). Bandung: Refika Aditama Supriyadi, A. 1997. Pola kemitraan Usaha Kecil, Menengah dan Besar Di masa yang akan Datang. Jakarta: Makalah dalam Temu Nasional Modal Ventura

Timothy, James. 2010. Membangun Bisnis Online, Jakarta: Elex Media Komputindo.

Wiwoho, Jamal. 2014. Peran lembaga keuangan bank dan lembaga 
keuangan bukan bank dalam memberikan Distribusi keadilan bagi masyarakat. $M M H$, Jilid $43 \mathrm{No}$. 1 Januari 